\title{
Development and Application of Health-Based Screening Levels for Use in Water-Quality Assessments
}

By Patricia L. Toccalino

National Water-Quality Assessment Program

Scientific Investigations Report 2007-5106 


\section{U.S. Department of the Interior \\ DIRK A. KEMPTHORNE, Secretary \\ U.S. Geological Survey \\ Mark D. Myers, Director}

U.S. Geological Survey, Reston, Virginia: 2007

For product and ordering information:

World Wide Web: http://www.usgs.gov/pubprod

Telephone: 1-888-ASK-USGS

For more information on the USGS--the Federal source for science about the Earth, its natural and living resources, natural hazards, and the environment:

World Wide Web: http://www.usgs.gov

Telephone: 1-888-ASK-USGS

Any use of trade, product, or firm names is for descriptive purposes only and does not imply endorsement by the U.S. Government.

Although this report is in the public domain, permission must be secured from the individual copyright owners to reproduce any copyrighted materials contained within this report.

Suggested reference:

Toccalino, P.L., Development and application of health-based screening levels for use in water-quality assessments: U.S. Geological Survey Scientific Investigations Report 2007-5106, $12 \mathrm{p}$. 


\section{FOREWORD}

The U.S. Geological Survey (USGS) is committed to providing the Nation with credible scientific information that helps to enhance and protect the overall quality of life and that facilitates effective management of water, biological, energy, and mineral resources (http://www.usgs.gov//). Information on the Nation's water resources is critical to ensuring long-term availability of water that is safe for drinking and recreation and is suitable for industry, irrigation, and fish and wildlife. Population growth and increasing demands for water make the availability of that water, now measured in terms of quantity and quality, even more essential to the long-term sustainability of our communities and ecosystems.

The USGS implemented the National Water-Quality Assessment (NAWQA) Program in 1991 to support national, regional, State, and local information needs and decisions related to water-quality management and policy (http://water.usgs.gov/nawqa). The NAWQA Program is designed to answer: What is the condition of our Nation's streams and ground water? How are conditions changing over time? How do natural features and human activities affect the quality of streams and ground water, and where are those effects most pronounced? By combining information on water chemistry, physical characteristics, stream habitat, and aquatic life, the NAWQA Program aims to provide science-based insights for current and emerging water issues and priorities. From 1991-2001, the NAWQA Program completed interdisciplinary assessments and established a baseline understanding of water-quality conditions in 51 of the Nation's river basins and aquifers, referred to as Study Units (http://water.usgs.gov/nawqa/studyu.html).

Multiple national and regional assessments are ongoing in the second decade (2001-2012) of the NAWQA Program as 42 of the 51 Study Units are reassessed. These assessments extend the findings in the Study Units by determining status and trends at sites that have been consistently monitored for more than a decade, and filling critical gaps in characterizing the quality of surface water and ground water. For example, increased emphasis has been placed on assessing the quality of source water and finished water associated with many of the Nation's largest community water systems. During the second decade, NAWOA is addressing five national priority topics that build an understanding of how natural features and human activities affect water quality, and establish links between sources of contaminants, the transport of those contaminants through the hydrologic system, and the potential effects of contaminants on humans and aquatic ecosystems. Included are topics on the fate of agricultural chemicals, effects of urbanization on stream ecosystems, bioaccumulation of mercury in stream ecosystems, effects of nutrient enrichment on aquatic ecosystems, and transport of contaminants to public-supply wells. These topical studies are conducted in those Study Units most affected by these issues; they comprise a set of multi-Study-Unit designs for systematic national assessment. In addition, national syntheses of information on pesticides, volatile organic compounds (VOCs), nutrients, selected trace elements, and aquatic ecology are continuing.

The USGS aims to disseminate credible, timely, and relevant science information to address practical and effective water-resource management and strategies that protect and restore water quality. We hope this NAWQA publication will provide you with insights and information to meet your needs, and will foster increased citizen awareness and involvement in the protection and restoration of our Nation's waters.

The USGS recognizes that a national assessment by a single program cannot address all water-resource issues of interest. External coordination at all levels is critical for cost-effective management, regulation, and conservation of our Nation's water resources. The NAWQA Program, therefore, depends on advice and information from other agencies_-Federal, State, regional, interstate, Tribal, and local — as well as nongovernmental organizations, industry, academia, and other stakeholder groups. Your assistance and suggestions are greatly appreciated.

Robert M. Hirsch

Associate Director for Water 
This page intentionally left blank. 


\section{Contents}

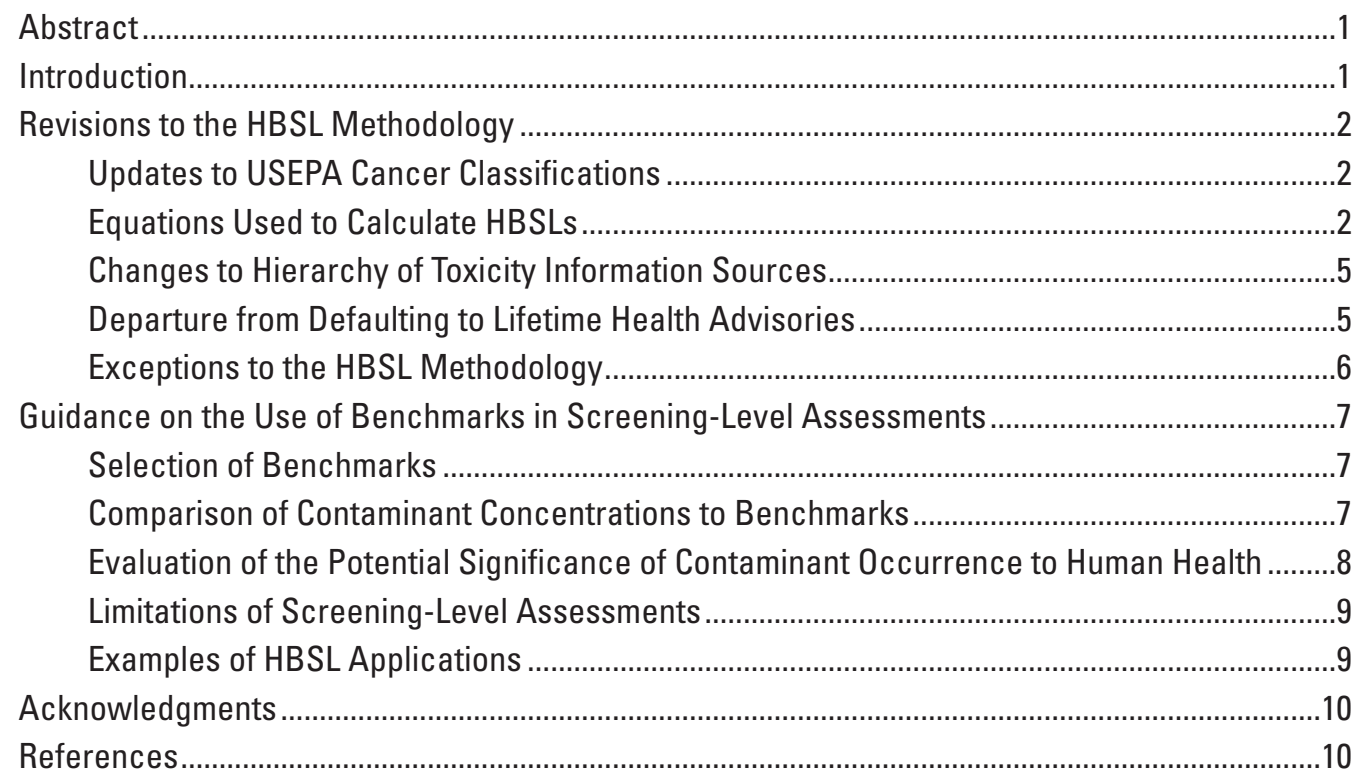

\section{Tables}

Table 1. Relationships between the alpha-numeric 1986 USEPA Weight-of-Evidence cancer classifications and the three equations used to calculate HBSLs................ 4

Table 2. Relationships between the descriptive 1996, 1999, and 2005 USEPA Weight-ofEvidence cancer classifications and the three equations used to calculate

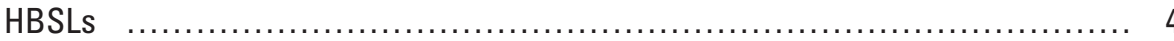

Table 3. The most recent USEPA sources of cancer classifications and toxicity data

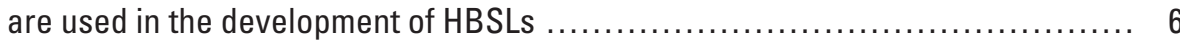

Table 4. Interpretation of Benchmark Quotients in relation to potential human-health significance and implications for water-quality monitoring $\ldots \ldots \ldots \ldots \ldots \ldots \ldots \ldots$ 


\section{Abbreviations and Acronyms}

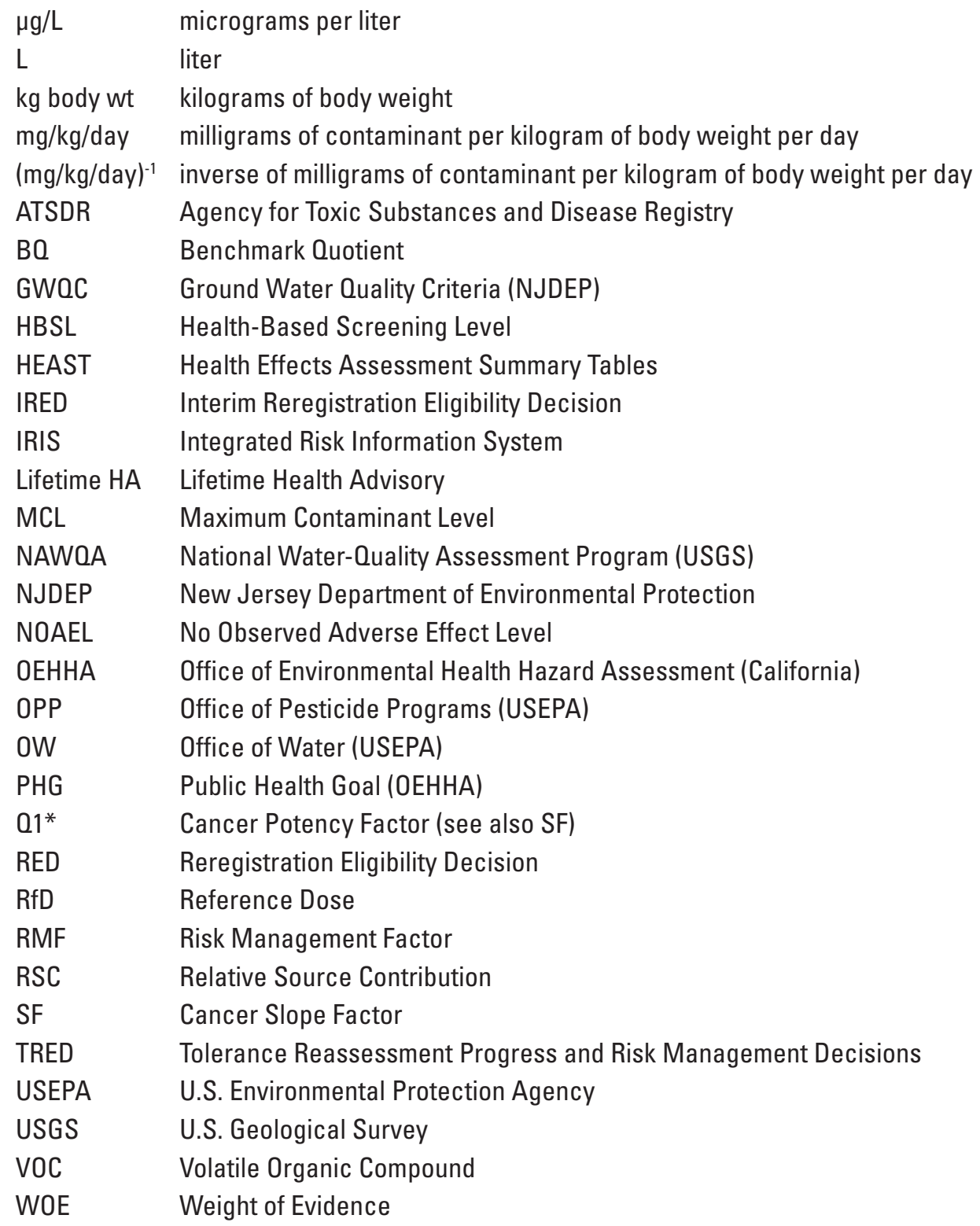




\title{
Development and Application of Health-Based Screening Levels for Use in Water-Quality Assessments
}

\author{
By Patricia L. Toccalino
}

\section{Abstract}

Health-Based Screening Levels (HBSLs) are nonenforceable water-quality benchmarks that were developed by the U.S. Geological Survey in collaboration with the U.S. Environmental Protection Agency (USEPA) and others. HBSLs supplement existing Federal drinking-water standards and guidelines, thereby providing a basis for a more comprehensive evaluation of contaminant-occurrence data in the context of human health. Since the original methodology used to calculate HBSLs for unregulated contaminants was published in 2003, revisions have been made to the HBSL methodology in order to reflect updates to relevant USEPA policies. These revisions allow for the use of the most recent, USEPA peerreviewed, publicly available human-health toxicity information in the development of HBSLs. This report summarizes the revisions to the HBSL methodology for unregulated contaminants, and updates the guidance on the use of HBSLs for interpreting water-quality data in the context of human health.

\section{Introduction}

Many water resources sampled by the U.S. Geological Survey (USGS) are used as drinking-water sources. Waterquality conditions in these assessments historically have been evaluated, where appropriate, by comparing measured contaminant concentrations to drinking-water standards or guidelines. Federal drinking-water standards and guidelines have not been established for about half of the organic contaminants most routinely analyzed in water by the USGS (Toccalino and others, 2005). Thus, in May 2001, interagency consensus was reached on a methodology for developing Health-Based Screening Level (HBSL) values for unregulated contaminants (sidebar 1) to be used as benchmarks for interpreting water-quality data in a human-health context (Toccalino and others, 2003). HBSLs supplement established Federal drinking-water standards and guidelines, thereby providing a basis for a more comprehensive evaluation of contaminant-occurrence data in the context of human health (Toccalino and others, 2005).

\section{Sidebar 1. Health-Based Screening Levels (HBSLs)}

HBSLs are benchmark concentrations of contaminants in water that, if exceeded, may be of potential concern for human health. HBSLs are non-enforceable benchmarks that were developed by the USGS in collaboration with the USEPA and others using: (1) USEPA methodologies for establishing drinking-water guidelines, and (2) the most recent, USEPA peerreviewed, publicly available human-health toxicity information (Toccalino and others, 2003; Toccalino and others, 2006b). The USGS and its cooperators continue to refine the HBSL methodology.

HBSLs are based on health effects alone and do not consider cost or technical limitations. For carcinogens, the HBSL range represents the contaminant concentration in drinking water that corresponds to an excess estimated lifetime cancer risk of 1 chance in 1 million to 1 chance in 10 thousand. For noncarcinogens, the HBSL represents the maximum contaminant concentration in drinking water that is not expected to cause any adverse effects over a lifetime of exposure. HBSL calculations adopt USEPA assumptions for establishing drinkingwater guidelines, specifically, lifetime ingestion of 2 liters of water per day by a 70-kilogram adult. For noncarcinogens, it also typically is assumed that 20 percent of the total contaminant exposure comes from drinking-water sources and that 80 percent comes from other sources (for example, food and air).

The original methodology for calculating HBSLs was published in 2003 with co-authors from the USGS, the U.S. Environmental Protection Agency (USEPA), the New Jersey Department of Environmental Protection (NJDEP), and the Oregon Health \& Science University (Toccalino and others, 2003). The consensus HBSL methodology for unregulated contaminants uses existing USEPA Office of Water (OW) equations for establishing drinking-water guidelines. As referred to in this report, unregulated contaminants are those without Federal drinking-water standards established under the Safe Drinking Water Act. 
Since 2003, revisions have been made to the HBSL methodology for unregulated contaminants in order to reflect updates to relevant USEPA policies, and this report summarizes these revisions. These revisions resulted from meetings between the USGS and the USEPA OW in August and September 2005 and continuing discussions with USEPA OW throughout the remainder of 2005. These meetings and discussions took place as part of the review process for USGS Circular 1292 (Zogorski and others, 2006), in which the USGS National Water-Quality Assessment (NAWQA) Program completed a national assessment of volatile organic compounds (VOCs) in ground water. HBSLs were used in Circular 1292 in a screening-level assessment to provide an initial nationalscale perspective on the potential significance of unregulated VOC concentrations to human health. HBSLs used in Circular 1292 and provided on the HBSL website (Toccalino and others, 2006a) were calculated using the methodology presented in this report.

The purpose of this report is to summarize the revisions to the HBSL methodology for unregulated contaminants and to update guidance on the use of HBSLs for interpreting water-quality data in the context of human health.

\section{Revisions to the HBSL Methodology}

HBSLs for unregulated contaminants are calculated using standard USEPA OW equations for establishing drinkingwater guideline values (Lifetime Health Advisory (Lifetime HA) and Cancer Risk Concentration values) for the protection of human health; this general approach has not changed since the original HBSL methodology was published (Toccalino and others, 2003).

The revisions to the HBSL methodology presented in this report reflect updates to USEPA cancer classifications, relationships between the equations used to calculate HBSLs and USEPA cancer classifications, changes to the hierarchy of toxicity information sources used to calculate HBSLs, and a departure from defaulting to Lifetime HA values as HBSLs for contaminants with certain cancer classifications. Additionally, this report outlines conditions under which exceptions to the HBSL methodology are made.

\section{Updates to USEPA Cancer Classifications}

Cancer classifications from the 1986, 1996, 1999, and 2005 USEPA guidelines for cancer risk assessment are considered in the development of HBSLs (U.S. Environmental Protection Agency, 1986, 1996, 1999, and 2005). The finalization of the USEPA cancer guidelines in 2005 (U.S. Environmental Protection Agency, 2005) does not change the HBSL methodology, but the HBSL methodology has been updated in this report to include the final USEPA cancer classifications.
Early USEPA cancer classifications used alpha-numeric cancer group designations that reflect a qualitative Weight-ofEvidence (WOE) judgment as to the likelihood that a contaminant may be a carcinogen for humans (U.S. Environmental Protection Agency, 1986). Subsequent USEPA draft guidelines (1996 and 1999) and the final 2005 USEPA guidelines for carcinogen risk assessment use descriptive terms for carcinogenicity that replace the earlier alpha-numeric cancer group designations (U.S. Environmental Protection Agency, 2005). The descriptive WOE judgments reflect the likelihood that a contaminant is a human carcinogen and the conditions under which the carcinogenic effects may be expressed. Some contaminants have not yet been evaluated under the final 2005 guidelines, so there are examples of contaminants with cancer classifications explained in the 1986, 1996, 1999, or 2005 guidelines.

\section{Equations Used to Calculate HBSLs}

Three USEPA OW equations are used to calculate HBSLs for unregulated contaminants as determined by the USEPA cancer classification for each chemical. These three equations have not changed since the publication of the original HBSL methodology (Toccalino and others, 2003), although the definitions for some terms used in the equations have been clarified. The USEPA's assumptions for establishing drinkingwater guidelines-lifetime ingestion of 2 liters (L) of water per day by a 70-kilogram adult (sidebar 1) - are adopted in each equation.

For carcinogens, the OW equation for calculating Cancer Risk Concentration values is used to calculate an HBSL range. The HBSL range represents a contaminant concentration range in drinking water corresponding to an excess estimated lifetime cancer risk of 1 chance in 1 million $\left(10^{-6}\right)$ to 1 chance in ten thousand $\left(10^{-4}\right)$ (eq. 1). HBSL concentration ranges for carcinogens were developed to be consistent with USEPA procedures and to acknowledge the uncertainty of the estimates. For carcinogens in drinking water, the USEPA considers risk levels of $10^{-6}$ (and for some compounds, risk levels as high as $10^{-4}$ ) to be protective of human health, provided these levels also are protective of noncancer adverse effects (U.S. Environmental Protection Agency, 1988). The USEPA accepts cancer risk policies from states in the range of $10^{-6}$ to $10^{-4}$ (U.S. Environmental Protection Agency, 1992 and 1995). Cancer Risk Concentration values were called Risk Specific Dose values in earlier HBSL documents (Toccalino and others, 2003; Toccalino and others, 2004; Toccalino and others, 2005). 


$$
\operatorname{HBSL}(\mu \mathrm{g} / \mathrm{L})=\frac{(70 \mathrm{~kg} \text { body wt }) \times(\text { risk level })}{(2 \mathrm{~L} \text { water consumed } / \text { day }) \times\left(\mathrm{SF}[\mathrm{mg} / \mathrm{kg} / \text { day }]^{-1}\right) \times(\mathrm{mg} / 1,000 \mu \mathrm{g})}
$$

Where

$$
\begin{aligned}
\mu \mathrm{g} / \mathrm{L} & =\text { micrograms per liter; } \\
\mathrm{kg} \text { body wt } & =\text { kilograms of body weight; } \\
\text { risk level } & \text { is } \quad 10^{-6} \text { to } 10^{-4} \text { cancer risk range; } \\
\mathrm{SF} & =\text { cancer slope factor (sidebar } 2) \\
(\mathrm{mg} / \mathrm{kg} / \mathrm{day})^{-1} & =\text { inverse of milligrams of chemical per kilogram of body weight per day; } \\
\mathrm{mg} & =\text { milligrams; and } \\
\mu \mathrm{g} & =\text { micrograms }
\end{aligned}
$$

For possible (Group C) carcinogens or contaminants with suggestive evidence of carcinogenic potential, HBSLs are calculated using the OW equation for calculating Lifetime HA values for Group C carcinogens (eq. 2). Equation 2 is the same as that presented in the original HBSL methodology report (Toccalino and others, 2003) except to clarify that the Relative Source Contribution (RSC) and the Risk Management Factor (RMF) values may differ from their default values. For noncarcinogens, HBSLs are calculated using the OW equation for calculating Lifetime HA values (eq. 3).

$\operatorname{HBSL}(\mu \mathrm{g} / \mathrm{L})=\left[\frac{(\mathrm{RfD}[\mathrm{mg} / \mathrm{kg} / \text { day }]) \times(70 \mathrm{~kg} \text { body } \mathrm{wt}) \times(1,000 \mu \mathrm{g} / \mathrm{mg}) \times \mathrm{RSC}}{(2 \mathrm{~L} \text { water consumed } / \text { day })}\right] \div \mathrm{RMF}$

HBSL $(\mu \mathrm{g} / \mathrm{L})=\frac{(\mathrm{RfD}[\mathrm{mg} / \mathrm{kg} / \text { day }]) \times(70 \mathrm{~kg} \text { body } \mathrm{wt}) \times(1,000 \mu \mathrm{g} / \mathrm{mg}) \times \mathrm{RSC}}{(2 \mathrm{~L} \text { water consumed } / \text { day })}$

Where

$$
\begin{aligned}
\mathrm{RfD} & =\text { reference dose (sidebar 2); } \\
\mathrm{mg} / \mathrm{kg} / \mathrm{day} & =\text { milligrams of chemical per kilogram of body weight per day; } \\
\mathrm{RSC} & =\text { Relative Source Contribution (defaults to } 20 \text { percent in the absence of other data); and } \\
\mathrm{RMF} & =\text { Risk Management Factor (defaults to } 10 \text { in the absence of other data) }
\end{aligned}
$$

\section{Sidebar 2. Cancer Slope Factors and Reference Doses}

Two types of toxicity values are used in the calculation of Health-Based Screening Levels (HBSLs). The toxicity value for carcinogens is the oral cancer Slope Factor (SF or $01^{*}$ ) and the toxicity value for noncarcinogens and possible carcinogens is the oral Reference Dose (RfD).

An oral SF is an upper bound, approximating a $95 \%$ confidence limit, on the increased cancer risk from a lifetime exposure to a contaminant. This estimate is generally reserved for use in the low-dose region of the dose-response relationship. If the model selected for extrapolation from dose-response data is the linearized multistage model, the SF value is also known as the $01^{*}$ (carcinogenic potency factor) value (U.S. Environmental Protection Agency, 1989a and 1993). Units for SF are (mg/kg/day) ${ }^{-1}$.

An oral RfD is an estimate (with uncertainty spanning perhaps an order of magnitude) of a daily oral exposure to the human population (including sensitive subgroups) that is likely to be without an appreciable risk of deleterious effects during a lifetime (U.S. Environmental Protection Agency, 2006a). Units for RfD are mg/kg/day. 
The relationships between USEPA WOE cancer classifications and the corresponding OW equations used to calculate HBSLs are shown in Tables 1 and 2 .

Table 1. Relationships between the alpha-numeric 1986 USEPA Weight-of-Evidence cancer classifications and the three equations used to calculate HBSLs.

[USEPA, U.S. Environmental Protection Agency; HBSL, Health-Based Screening Level; USEPA OW, Office of Water]

1986 USEPA Weight-of-Evidence Descriptors

(U.S. Environmental Protection Agency, 1986)

OW equation used to calculate HBSL

\begin{tabular}{ll}
\hline A - Known human carcinogen & Cancer Risk Concentration (eq. 1) \\
B1, B2 - Probable human carcinogen & Cancer Risk Concentration (eq. 1) \\
C - Possible human carcinogen & Lifetime Health Advisory (Lifetime HA) for Group C carcinogens (eq. 2) \\
D - Unclassifiable & Lifetime HA (eq. 3) \\
E - Evidence of non-carcinogenicity for humans & Lifetime HA (eq. 3) \\
No Weight-of-Evidence descriptor, but reference dose is available & Lifetime HA (eq. 3) \\
\hline
\end{tabular}

Table 2. Relationships between the descriptive 1996, 1999, and 2005 USEPA Weight-of-Evidence cancer classifications and the three equations used to calculate HBSLs.

[USEPA, U.S. Environmental Protection Agency; HBSL, Health-Based Screening Level; USEPA OW, Office of Water]

USEPA Weight-of-Evidence Descriptors

1996 (U.S. Environmental

Protection Agency, 1996)

Known/likely

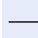

Cannot be determined

Not likely Multiple narrative descriptors such as: "Like

1999 (U.S. Environmental

Protection Agency, 1999)

Carcinogenic to humans

Likely to be carcinogenic to humans

Suggestive evidence of carcinogenicity but not sufficient to assess human carcinogenic potential

Data are inadequate for an assess- Ina ment of human carcinogenic potential

Not likely to be carcinogenic to

\section{OW equation used}

2005 (U.S. Environmental

Protection Agency, 2005)

Carcinogenic to humans

Cancer Risk Concentration (eq. 1)

Likely to be carcinogenic to humans

Suggestive evidence of carcino- Lifetime Health Advisory (Lifetime genic potential

HA) for Group C carcinogens

(eq. 2)

Inadequate information to assess Lifetime HA (eq. 3) carcinogenic potential Not likely to be carcinogenic to Lifetime HA (eq. 3)
humans

Lifetime HA (eq. 3) $)^{1}$

Lifetime HA (eq. 3)

No Weight-of-Evidence descriptor, but reference dose is available

${ }^{1}$ Equation 3 for Lifetime HA values is used with these types of multiple narrative Weight-of-Evidence descriptors because concentrations detected in the environment typically are low. 
Because HBSLs are calculated using USEPA cancer classifications, USEPA toxicity data, and standard OW equations for establishing drinking-water guideline values (eqs. 1-3), HBSLs are equivalent to existing USEPA Cancer Risk Concentration and Lifetime HA values (when they exist), except for compounds for which more recent toxicity information has become available. HBSLs are rounded to one significant figure, which is consistent with USEPA OW policy.

The OW equations used to calculate HBSLs (eqs. 1-3) are comparable to those used by a variety of state agencies to develop state drinking-water guidelines, although states may use different default exposure assumptions, sources of toxicity data, or modifications to OW's equations. For example, the NJDEP calculates ground-water-quality criteria (GWQC) for ground waters that have been designated for potable water use (New Jersey Department of Environmental Protection, 2004). The equations used to calculate GWQC values are the same as those used to calculate HBSLs, although for some Group $\mathrm{C}$ carcinogens, the NJDEP uses the equation for calculating Cancer Risk Concentration values (eq. 1) instead of the equation for Lifetime HA values for Group C carcinogens (eq. 2) (New Jersey Department of Environmental Protection, 2004). In California, non-regulatory Public Health Goals (PHGs) are developed by the Office of Environmental Health Hazard Assessment (OEHHA) to help maintain the quality of California's drinking-water supplies (California Environmental Protection Agency, 2003). PHGs are calculated using similar equations and default exposure assumptions as those used to calculate HBSLs, although for noncarcinogens, OEHHA may use different toxicity values (for example, no-observedadverse-effect-level (NOAEL) values and associated uncertainty factors instead of USEPA reference dose (RfD) values) (California Environmental Protection Agency, 2003). Additionally, PHGs for VOCs account for inhalation and dermal exposure through showering and other household uses of tap water, which decreases PHG values compared to considering ingestion exposure only. For carcinogens, GWQC and PHG values typically are established at the $10^{-6}$ cancer risk level, whereas HBSL values are calculated as concentration ranges that correspond to a cancer risk range of $10^{-6}$ to $10^{-4}$ (eq. 1); both approaches are consistent with USEPA procedures.

\section{Changes to Hierarchy of Toxicity Information Sources}

In the original HBSL methodology (Toccalino and others, 2003), a hierarchy of USEPA sources of cancer classifications and toxicity data (cancer slope factors and reference doses, sidebar 2) was used in the development of HBSLs. Cancer classifications and toxicity data from the USEPA Integrated Risk Information System (IRIS) database had the highest priority, followed by the most recent information from the USEPA OW and the Office of Pesticide Programs (OPP). Cancer classifications and toxicity data from the USEPA
Health Effects Assessment Summary Tables (HEAST) were assigned a lower priority and were used only in the absence of information from IRIS, OW, and OPP.

The USEPA and USGS participants in the AugustSeptember 2005 discussions agreed that the hierarchy of toxicity information used in HBSL development should change because the availability of toxicity information published by the USEPA has changed since the original HBSL methodology was published. Specifically, as part of the pesticide registration review program, the OPP periodically reevaluates toxicity information for pesticides. Updates to toxicity information for pesticides historically were published in the IRIS database and in OPP documents, but are now published in separate OPP risk assessment documents and reregistration eligibility decision documents (and typically not in the IRIS database) (A. Mills, IRIS Program Director, written commun., December 27, 2005). The discontinuation of pesticide toxicity information updates to the IRIS database affects the hierarchy of sources of toxicity information used in the development of HBSLs.

The hierarchy of toxicity information used in HBSL development also was changed to represent the current "state of the science" in the United States. The USEPA and USGS participants in the August-September 2005 discussions determined that "acceptable" toxicity information for developing HBSLs should meet four criteria: (1) United States information (limited to USEPA data); (2) internally (e.g., USEPA) or externally peer reviewed; (3) publicly available (so anyone has access to the information); and (4) most recently available.

The hierarchy of sources of cancer classifications and toxicity data to use in the development of HBSLs was changed to the most recent of five USEPA sources (table 3). Use of this hierarchy has the advantage of providing a mechanism for the timely incorporation of updated toxicity information in the interpretation of water-quality data. HEAST values are no longer used to derive HBSLs because these values are older, not necessarily peer reviewed, and are not readily available to the public.

\section{Departure from Defaulting to Lifetime Health Advisories}

In the original HBSL methodology, HBSLs for possible (Group C) carcinogens, contaminants with suggestive evidence of carcinogenic potential, and noncarcinogens defaulted to USEPA Lifetime HA values, when available (Toccalino and others, 2003). The revised HBSL methodology will no longer default to using Lifetime HA values. Instead, HBSLs are now derived using Equation 2 for possible carcinogens and contaminants with suggestive evidence of carcinogenicity, Equation 3 for noncarcinogens, and the most recent toxicity information as noted in Table 3. This revision to the HBSL methodology ensures that HBSLs are consistently based on the most recently available toxicity information. 
Table 3. The most recent USEPA sources of cancer classifications and toxicity data are used in the development of HBSLs.

[USEPA, U.S. Environmental Protection Agency; HBSL, Health-Based Screening Level]

USEPA data sources - the most recent USEPA data source for a given chemical is used for HBSL development

Integrated Risk Information System database (Office of Research and Development)

\section{Reference(s)}

(U.S. Environmental Protection Agency, 2006d)

Most recent edition of the "Drinking Water Standards and Health Advisories" document (Of- (U.S. Environmental Protection Agency, fice of Water) 2006a)

Pesticide Tolerance Reassessment and Reregistration documents (Office of Pesticide Programs (OPP)). Toxicity information is available in the following types of documents:

- Reregistration Eligibility Decision (RED)

- Interim Reregistration Eligibility Decision (IRED)

- Reports on Food Quality Protection Act Tolerance Reassessment Progress and [Interim] Risk Management Decisions (TRED)

- Risk Assessments in support of RED, IRED, or TRED documents

Most recent edition of "Chemicals Evaluated for Carcinogenic Potential" document (OPP)

Reference Dose Tracking Report (OPP). All reference dose values from the Reference Dose Tracking Report are verified by OPP's Science Information Management Branch, Health Effects Division, before using to calculate HBSLs because this report has not been updated since 1997. The OPP data sources listed above take precedence over data from the Reference Dose Tracking Report.

\section{Exceptions to the HBSL Methodology}

When an HBSL differs from an existing USEPA Lifetime HA value and the reason for the difference is not apparent (for example, the same OW toxicity value and equation are used for the HBSL and Lifetime HA), the USGS will consult with the USEPA OW to identify the reason for the discrepancy. The USEPA OW may have technical or policy reasons for modifying the equations for calculating Lifetime HA values for some compounds (J. Donohue, OW, Office of Science and Technology, written commun., January 20, 2006) such as:

- Noncarcinogens for which the RSC is different from the USEPA default value of 20 percent.

- Possible (Group C) carcinogens or contaminants with suggestive evidence of carcinogenic potential for which the RMF is different from the USEPA default value of 10. USEPA policy allows for RMF values to range from 1 to 10 .

- Compounds for which different rounding procedures were used. OW has calculated Lifetime HA values using RfD values that were rounded to one significant figure for some compounds and not rounded to one significant figure for other compounds. HBSLs are calculated using the most recent, USEPA peer-reviewed, publicly available toxicity values, as published, regardless of the number of significant figures.
For those compounds with differing HBSL and Lifetime HA values, the HBSL will default to the Lifetime HA value when:

1. The HBSL is based on OW toxicity data (that is, OW has the most recently published toxicity information).

2. OW has established an RSC or RMF for a compound that differs from the default values of $20 \%$ and 10 , respectively, regardless of whether the HBSL is derived using OW, OPP, or IRIS toxicity data. OW is the only USEPA office with policies on the development and use of RSC and RMF values.

The rationale for any exceptions to the HBSL methodology will be captured on the HBSL website (Toccalino and others, 2006a). 


\section{Guidance on the Use of Benchmarks in Screening-Level Assessments}

In screening-level water-quality assessments, estimates of potential contaminant exposure (concentrations or concentration statistics determined from measurements of contaminants in ground water or surface water) are compared to water-quality benchmarks derived for the protection of human health. Screening-level assessments provide an initial perspective on the potential significance of detected contaminants to human health and help prioritize further investigations (Toccalino and others, 2006b). They also provide a perspective on where adverse effects are more likely to occur and what contaminants may be responsible for those effects (Gilliom and others, 2006). Screening-level assessments are not designed to evaluate specific effects of contaminants on human health, and are not a substitute for comprehensive risk assessments, which generally include many additional factors, including multiple avenues of exposure (Toccalino and others, 2006b).

Initial guidance on the use of benchmarks for evaluating water-quality data in the context of human health was provided in a state-scale pilot study (Toccalino and others, 2004). This report updates that guidance, which also is periodically updated on the HBSL website (Toccalino and others, 2006a).

\section{Selection of Benchmarks}

In screening-level assessments, contaminant concentrations or concentration statistics for regulated contaminantsthose with USEPA Maximum Contaminant Levels (MCLs) (sidebar 3) - are compared to their MCLs as benchmarks, and concentrations of unregulated contaminants - those without USEPA MCLs-are compared to their HBSLs as benchmarks, when available (Toccalino and others, 2003). For local and state-scale water-quality assessments, concentrations of contaminants that are regulated by the USEPA and (or) the state in which the assessment takes place, are compared to USEPA and state drinking-water standards (Toccalino and others, 2003). State MCLs, when they exist, are equal to, or more stringent than, USEPA MCLs.

\section{Sidebar 3. Maximum Contaminant Levels (MCLs)}

MCLs are legally enforceable USEPA drinking-water standards that set the maximum permissible level of a contaminant in water that is delivered to any user of a public water system. MCLs are set as close as feasible to the maximum level of a contaminant at which no known or anticipated adverse effects on human health would occur over a lifetime, taking into account the best available technology, treatment techniques, cost considerations, expert judgment, and public comments (U.S. Environmental Protection Agency, 2006e).
The most current USEPA MCL values are published in the Code of Federal Regulations (U.S. Environmental Protection Agency, 2002) and in periodic USEPA compilations of drinking-water contaminants and their MCLs (U.S. Environmental Protection Agency, 2006a and 2006c). State MCLs typically are published on state drinking-water program web sites. The most current HBSL values are posted on the HBSL web site (Toccalino and others, 2006a).

\section{Comparison of Contaminant Concentrations to Benchmarks}

HBSLs, as well as most MCLs, are maximum contaminant concentrations that are not expected to cause adverse health effects over a lifetime of exposure to drinking water (sidebars 1 and 3). Therefore, contaminant concentrations or concentration statistics indicative of long-term exposure are most appropriate to compare to MCLs or HBSLs in most applications. In ground water, contaminant concentrations tend to change slowly over time, and therefore it is appropriate for the purpose of screening-level assessments to compare ground-water contaminant concentrations measured in individual well samples to MCLs or HBSLs. Examples of groundwater assessments for which the frequency distribution of contaminant concentrations was compared to MCLs or HBSLs are provided in various USGS reports (see figures 4 and 5 in Toccalino and others (2004) and appendix 7 in Zogorski and others (2006)). Such analyses indicate the proportion of detections that are greater than, or within a certain fraction of, MCLs or HBSLs, and also may present the number of samples collected and detection frequencies for each contaminant.

In contrast to concentrations in ground water, surfacewater contaminant concentrations generally change substantially over time and have strong seasonal patterns. For screening-level assessments of surface water, annual or long-term mean (average) concentrations (determined from multiple samples over a period of time and time-weighted) generally are most appropriate for comparison to MCLs or HBSLs because mean concentrations provide a more reliable indication of long-term exposure than concentrations from individual samples. If surface-water data are insufficient for the calculation of a reliable mean concentration, then comparison of contaminant concentrations from individual samples to MCLs or HBSLs can be a useful first step if caution is exercised (see the section "Evaluation of the Potential Significance of Contaminant Occurrence to Human Health"). Chapter 6 of NAWQA's national assessment of pesticides in streams and ground water (Gilliom and others, 2006) provides examples of surface-water assessments where annual mean concentrations of pesticides are compared to water-quality benchmarks for human health. 
When evaluating the potential significance of contaminant occurrence data to human health, the analytical minimum reporting level for each contaminant should be less than its MCL or HBSL. This ensures that the laboratory methodologies are adequate to detect concentrations relevant to human health. If the minimum reporting level for a contaminant is greater than its MCL or HBSL, then (a) the contaminant may be present at a concentration greater than a benchmark but not be detected (U.S. Environmental Protection Agency, 1989b), and (b) there is greater uncertainty in evaluating the contaminant concentration or concentration statistic in the context of human health (Toccalino and others, 2004).

Benchmark Quotient (BQ) values can be calculated to aid in evaluating water-quality data in the context of human health. $\mathrm{BQ}$ values are ratios of the contaminant concentrations or concentration statistics to their respective MCLs (for regulated contaminants) or HBSLs (for unregulated contaminants). For unregulated carcinogens, BQ values are first calculated using the low end of the HBSL range, which corresponds to a $10^{-6}$ cancer risk. If a $\mathrm{BQ}$ value for a carcinogen is greater than 1 using the low end of the HBSL range, then a BQ value using the high end of the HBSL range, which corresponds to a $10^{-4}$ cancer risk, also is calculated. BQ values are rounded to one significant figure (Toccalino and others, 2004). Figures 6, 7, and 8 in Toccalino and others (2004) show examples of how distributions of BQ values can be graphed to interpret water-quality findings for a state-scale ground-water assessment.

\section{Evaluation of the Potential Significance of Contaminant Occurrence to Human Health}

Benchmark Quotients are useful in screening-level assessments for determining the potential significance of contaminant occurrence in water to human health (table 4). A BQ value greater than 1 signifies a contaminant concentra- tion of potential human-health concern if the computed BQ value is indicative of a long-term average concentration and if the water were to be ingested, without treatment, over a lifetime as the primary drinking-water source (Toccalino and others, 2006b). The likelihood for adverse effects generally increases as a contaminant concentration increases above its benchmark (and its BQ value increases above 1) (Gilliom and others, 2006). Contaminants with concentrations or concentration statistics of the greatest potential human-health concern typically are those that both have BQ values greater than 1 and are frequently detected. Drinking-water standards (MCLs) are not violated, however, if concentrations of regulated contaminants are greater than MCLs (BQ values are greater than 1) in ground-water or surface-water samples, because samples collected by the USGS are not collected for compliance with the Safe Drinking Water Act (Toccalino and others, 2006b).

Ingestion of water containing a contaminant with a BQ value less than 1 is unlikely to result in adverse human-health effects resulting from that contaminant alone (table 4)

(Toccalino and others, 2006b). For surface-water assessments, in particular, if only one or a few samples are available and data are insufficient to calculate a reliable mean concentration, $B Q$ values less than 1 do not lead to a definitive screeninglevel conclusion because the probability is low that a small number of samples would include high contaminant concentrations that occur infrequently.

$\mathrm{A} B Q$ value greater than or equal to $0.1 \mathrm{can}$ be used to identify compounds that may warrant additional monitoring (table 4) (Toccalino and others, 2006b). Although a variety of $B Q$ values may be selected as threshold values to identify contaminants that may warrant further monitoring, a threshold BQ of 0.1 is consistent with various state and Federal practices (for example, see U.S. Environmental Protection Agency, 1998). Regular monitoring of such contaminants would enable analysis of trends in their occurrence and provide an early indication of contaminant concentrations that approach MCLs or HBSLs (Toccalino and others, 2006b).

Table 4. Interpretation of Benchmark Quotients in relation to potential human-health significance and implications for water-quality monitoring.

[Benchmark Quotient: The ratio of a contaminant concentration or an appropriate concentration statistic indicative of long-term exposure to its MCL or HBSL. Abbreviations: $\leq$, less than or equal to; >, greater than; MCL, Maximum Contaminant Level; HBSL, Health-Based Screening Level; $\geq$, greater than or equal to]

\begin{tabular}{cc}
\hline $\begin{array}{c}\text { Benchmark Quotient } \\
\text { for a contaminant } \\
\text { in water }\end{array}$ & \\
\hline$\leq 1$ & $\begin{array}{c}\text { Adverse effects are unlikely to be caused by this contaminant alone, even if water with such a concentration were to } \\
\text { be ingested over a lifetime. } \\
\text { The contaminant concentration is of potential human-health concern if water with such a concentration were to be } \\
\text { ingested without treatment over a lifetime. Adverse human-health effects will not necessarily be caused by this } \\
\text { contaminant because MCLs and HBSLs are conservative (protective); they incorporate safety factors to account for } \\
\text { uncertainty in toxicity information. Additionally, water may be treated or blended, potentially reducing contami- } \\
\text { nant concentrations. } \\
\text { Contaminant may warrant additional monitoring to analyze trends in its occurrence and to provide an early indication } \\
\text { of a contaminant concentration that approaches its benchmark. }\end{array}$ \\
\hline 0.1 &
\end{tabular}


Interpretation of the potential significance of contaminant occurrence to human health also should consider the type of water sampled. For example, ground water from domestic wells, which typically is used by a single family, often is consumed with little or no treatment. Ground water from public-supply wells and surface water from water-supply intakes usually is treated or blended before distribution and (or) consumption, potentially reducing contaminant concentrations, but often is used by many people. Ground-water data from monitoring wells are not directly relevant to human health because this water is not consumed, but contamination in monitoring wells can indicate the potential for future contamination in deeper aquifers used for drinking-water supplies (Toccalino and others, 2004). Likewise, surface-water samples that are not collected at water-supply intakes are not directly applicable to drinking-water supplies. Results from such surface-water samples, however, can be used to provide a perspective on the potential significance to human health for source water with similar watershed land uses (Gilliom and others, 2006), or if the sampled water body is considered a potential future source of drinking water.

If information about the potential health effects associated with specific contaminants in drinking-water supplies is needed for a particular water-quality assessment, such information may be obtained from sources such as the USEPA and the Agency for Toxic Substances and Disease Registry (ATSDR). The ATSDR is a Federal public-health agency of the U.S. Department of Health and Human Services. The USEPA publishes fact sheets for many compounds with MCLs (U.S. Environmental Protection Agency, 2006c) and the ATSDR publishes Toxicological Profiles and ToxFAQs (summaries about chemical exposure and the effects of exposure on human health) (Agency for Toxic Substances and Disease Registry, 2007a; Agency for Toxic Substances and Disease Registry, 2007b).

\section{Limitations of Screening-Level Assessments}

Screening-level assessments are a useful first step toward evaluating contaminant occurrence in the context of human health, but such assessments have limitations. For example, MCLs and HBSLs generally are developed using toxicity information for single contaminants, whereas it is common to detect contaminant mixtures in ground water and surface water. The long-term cumulative effects of low concentrations of multiple contaminants on human health currently are unknown for most contaminant combinations. An additional limitation is that HBSLs have not been developed for some unregulated contaminants because of a lack of toxicity information; the potential human-health significance of the occurrence of contaminants without benchmarks cannot, therefore, be evaluated at this time (Toccalino and others, 2006b). It is, however, useful to identify those unregulated contaminants that most frequently occur in a given assessment, but do not have HBSLs. As improved data on toxicity and environmental concentrations are developed, HBSLs and exposure estimates can be updated, and screening-level assessments can be improved and expanded. The USGS works closely with the USEPA to assist them with incorporating water-quality findings into their risk assessments (Gilliom and others, 2006).

\section{Examples of HBSL Applications}

Several published studies have used HBSLs to help provide an initial perspective on the potential human-health significance of contaminant concentrations in water. These studies also provide examples of analyses and language applied to the use of HBSLs and MCLs as water-quality benchmarks:

- National assessment of VOCs in ground water (Zogorski and others, 2006) and a corresponding Fact Sheet about what those findings may mean to human health (Toccalino and others, 2006b).

- National assessment of pesticides in streams and ground water (Gilliom and others, 2006). This assessment did not use HBSLs, but it contains examples of the application of MCL, Lifetime HA, and Cancer Risk Concentration values as water-quality benchmarks in the context of human health.

- State-scale analyses of the occurrence of anthropogenic organic compounds in ground water and finished water of community water systems in Nevada (Rosen and others, 2006) and the northern Tampa Bay area in Florida (Metz and others, 2006).

- Fact Sheet providing background on the HBSL effort (Toccalino and others, 2005).

- State-scale analyses that applied HBSLs to groundwater quality data in New Jersey (Toccalino and Norman, 2006; Toccalino and others, 2004). Both of these documents use HBSLs calculated using the original methodology, and not the revised HBSL methodology described in this report.

- Original HBSL methodology and history of the HBSL effort (Toccalino and others, 2003). 


\section{Acknowledgments}

The author gratefully acknowledges the collaboration of several colleagues at the USEPA OW who helped to shape the revisions to the HBSL methodology described in this report. Representatives from USEPA OW Office of Science and Technology and Office of Ground Water and Drinking Water provided critical contributions to the revised HBSL methodology at meetings held August 31 and September 15, 2005, in Washington, DC, and in subsequent discussions.

\section{References}

Agency for Toxic Substances and Disease Registry, 2007a, ToxFAQs: U.S. Department of Health and Human Services, Centers for Disease Control, Agency for Toxic Substances and Disease Registry, Updated January 18, 2007, Accessed January 18, 2007, at http://www.atsdr.cdc.gov/toxfaq.html

Agency for Toxic Substances and Disease Registry, 2007b, Toxicological profile information sheet: U.S. Department of Health and Human Services, Centers for Disease Control, Agency for Toxic Substances and Disease Registry, Updated January 18, 2007, Accessed January 18, 2007, at http:// www.atsdr.cdc.gov/toxpro2.html

California Environmental Protection Agency, 2003, Guide to public health goals (PHGs) for chemicals in drinking water: California Environmental Protection Agency, Office of Environmental Health Hazard Assessment, October 2003, Accessed March 28, 2007, at http://www.oehha.ca.gov/ water/phg/pdf/PHGfacts.pdf

Gilliom, R.J., Barbash, J.E., Crawford, C.G., Hamilton, P.A., Martin, J.D., Nakagaki, N., Nowell, L.H., Scott, J.C., Stackelberg, P.E., Thelin, G.P., and Wolock, D.M., 2006, The quality of our Nation's waters-Pesticides in the Nation's streams and ground water, 1992-2001: U.S. Geological Survey Circular 1291, 172 p., http://ca.water.usgs.gov/pnsp/ pubs/circ1291/

Metz, P.A., Delzer, G.C., Berndt, M.P., Crandall, C.A., and Toccalino, P.L., in press, Anthropogenic organic compounds in ground water and finished water of community water systems in the northern Tampa Bay area, Florida, 2002-2004: U.S. Geological Survey Scientific Investigations Report 2006-5267.
New Jersey Department of Environmental Protection, 2004, Basis and background for criteria derivation and practical quantitation levels-Ground water quality standards rule recodification and readoption with amendments N.J.A.C 7:9C: New Jersey Department of Environmental Protection, September 2004, Accessed March 28, 2007, at http://www. state.nj.us/dep/wms/bwqsa/docs/gwqsbb.pdf

Regulations.gov, 2007, Regulations.gov your voice in federal decision making. Electronic docket for USEPA documents: Updated January 17, 2007, Accessed January 17, 2007, at http://www.regulations.gov/fdmspublic/component/main

Rosen, M.R., Schaefer, D.H., Toccalino, P.L., and Delzer, G.C., 2006, Occurrence of anthropogenic organic compounds in ground water and finished water of community water systems in Eagle and Spanish Springs Valleys, Nevada, 2002-2004: U.S. Geological Survey Scientific Investigations Report 2006-5210, 43 p., http://pubs.usgs. gov/sir/2006/5210/pdf/SIR065210.pdf

Toccalino, P.L., and Norman, J.E., 2006, Health-based screening levels to evaluate U.S. Geological Survey ground-water quality data: Risk Analysis, v. 26, no. 5, p. 1339-1348.

Toccalino, P.L., Norman, J.E., Booth, N.L., and Zogorski, J.S., 2006a, Health-based screening levels-A tool for evaluating what water-quality data may mean to human health: U.S. Geological Survey, National Water-Quality Assessment Program, Updated December 14, 2006, Accessed January 17, 2007, at http://water.usgs.gov/nawqa/HBSL

Toccalino, P.L., Norman, J.E., Phillips, R.H., Kauffman, L.J., Stackelberg, P.E., Nowell, L.H., Krietzman, S.J., and Post, G.B., 2004, Application of health-based screening levels to ground-water quality data in a state-scale pilot effort: U.S. Geological Survey Scientific Investigations Report 2004-5174, 64 p., http://pubs.usgs.gov/sir/2004/5174/ sir20045174.pdf

Toccalino, P.L., Nowell, L.H., Wilber, W.G., Zogorski, J.S., Donohue, J.M., Eiden, C.A., Krietzman, S.J., and Post, G.B., 2003, Development of health-based screening levels for use in state- or local-scale water-quality assessments: U.S. Geological Survey Water-Resources Investigations Report 03-4054, 22 p., http://sd.water.usgs.gov/nawqa/ pubs/wrir/wrir03 4054.pdf

Toccalino, P.L., Rowe, B.L., and Norman, J.E., 2006b, Volatile organic compounds in the Nation's drinking-water supply wells-what findings may mean to human health: U.S. Geological Survey Fact Sheet 2006-3043, 4 p., http://pubs. usgs.gov/fs/2006/3043/ 
Toccalino, P.L., Zogorski, J.S., and Norman, J.E., 2005, Health-based screening levels and their application to waterquality data: U.S. Geological Survey Fact Sheet 2005-2059, 2 p., http://water.usgs.gov/nawqa/FS 2005-3059.pdf

U.S. Environmental Protection Agency, 1986, Guidelines for carcinogen risk assessment: Washington, DC, U.S. Environmental Protection Agency, Office of Research and Development, National Center for Environmental Assessment Federal Register EPA/630/R-00/004, September 24, 1986, p. 33992-34003, http://www.epa.gov/ncea/raf/rafguid.htm

U.S. Environmental Protection Agency, 1988, Draft guide to drinking water health advisories: Washington, DC, U.S. Environmental Protection Agency, Office of Drinking Water, Criteria and Standards Division, Health Effects Branch, August 25, 1988, variously paginated.

U.S. Environmental Protection Agency, 1989a, Drinking water health advisory, pesticides: Chelsea, MI, Lewis Publishers, $819 \mathrm{p}$.

U.S. Environmental Protection Agency, 1989b, Risk assessment guidance for superfund. Volume 1. Human health evaluation manual (Part A), interim final: Washington, DC, U.S. Environmental Protection Agency, Office of Emergency and Remedial Response EPA/540/1-89/002, December 1989, variously paginated, http://www.epa.gov/oswer/riskassessment/ragsa/pdf/preface.pdf

U.S. Environmental Protection Agency, 1992, Water quality standards-Establishment of numeric criteria for priority toxic pollutants; States' compliance; Final rule (12/22/92): Washington, DC, U.S. Environmental Protection Agency, December 22, 1992, Federal Register vol. 57, no. 246, p. 60848-60923.

U.S. Environmental Protection Agency, 1993, Health advisories for drinking water contaminants: Boca Raton, FL, Lewis Publishers, 260 p.

U.S. Environmental Protection Agency, 1995, Final water quality guidance for the Great Lakes system; final rule: Washington, DC, U.S. Environmental Protection Agency, March 23, 1995, Federal Register vol. 60, no. 56, p. $15365-15425$.

U.S. Environmental Protection Agency, 1996, Proposed guidelines for carcinogen risk assessment: Washington, DC, U.S. Environmental Protection Agency, Office of Research and Development EPA/600/P-92/003C, April 1996, 172 p., http://www.epa.gov/ORD/WebPubs/carcinogen/
U.S. Environmental Protection Agency, 1997, Reference dose tracking report: U.S. Environmental Protection Agency, Office of Pesticide Programs, Updated February 25, 1997, Accessed January 17, 2007, at http://ace.orst.edu/info/npic/ tracking.htm

U.S. Environmental Protection Agency, 1998, Code of Federal Regulations, title 40-protection of environment, chapter 1 -environmental protection agency, subchapter E-pesticide programs, part 159-statements of policies and interpretations, subpart D-reporting requirements for risk/ benefit information, 40 CFR 159.184: National Archives and Records Administration, September 19, 1997; amended June 19, 1998, Accessed February 12, 2007, at http://www. gpoaccess.gov/ecfr/index.html

U.S. Environmental Protection Agency, 1999, Guidelines for carcinogen risk assessment: Washington, DC, U.S. Environmental Protection Agency, Office of Research and Development, National Center for Environmental Assessment NCEA-F-0644, July 1999, 25 p., http://www.epa.gov/ncea/ raf/car2sab/preamble.pdf

U.S. Environmental Protection Agency, 2002, Code of Federal Regulations, title 40 - protection of environment, chapter 1-Environmental Protection Agency, part 141-national primary drinking water regulations, 40 CFR 141: National Archives and Records Administration, July 1, 2002, Accessed February 12, 2007, at http://www.access.gpo. gov/nara/cfr/waisidx 02/40cfr141 $02 . h t m l$

U.S. Environmental Protection Agency, 2005, Guidelines for carcinogen risk assessment: Washington, DC, Risk Assessment Forum EPA/630/P-03/001B, March 2005, http://cfpub. epa.gov/ncea/raf/recordisplay.cfm?deid=116283

U.S. Environmental Protection Agency, 2006a, 2006 Edition of the drinking water standards and health advisories: Washington, DC, U.S. Environmental Protection Agency, Office of Water EPA 822-R-06-013, August 2006, 18 p., http://www.epa.gov/waterscience/criteria/drinking/dwstandards.pdf

U.S. Environmental Protection Agency, 2006b, Chemicals evaluated for carcinogenic potential: Washington, DC, U.S. Environmental Protection Agency, Office of Pesticide Programs, Health Effects Division, Science Information Management Branch, April 26, 2006, 50 p., http://www.epa. gov/pesticides/carlist/

U.S. Environmental Protection Agency, 2006c, Drinking water contaminants: U.S. Environmental Protection Agency, Office of Water, Updated November 28, 2006, Accessed January 17, 2007, at http://www.epa.gov/safewater/contaminants/index.html 
U.S. Environmental Protection Agency, 2006d, Integrated Risk Information System: U.S. Environmental Protection Agency, Office of Research and Development, National Center for Environmental Assessment, Updated March 8, 2006, Accessed January 17, 2007, at http://www.epa. gov/iris/index.html

U.S. Environmental Protection Agency, 2006e, Setting standards for safe drinking water: U.S. Environmental Protection Agency, Office of Water, Office of Ground Water and Drinking Water, Updated November 28, 2006, Accessed January 17, 2007, at http://www.epa.gov/safewater/standard/setting.html
U.S. Environmental Protection Agency, 2007, Pesticide reregistration status: U.S. Environmental Protection Agency, Office of Pesticide Programs, Updated January 17, 2007, Accessed January 17, 2007, at http://cfpub.epa.gov/oppref/ rereg/status.cfm?show=rereg

Zogorski, J.S., Carter, J.M., Ivahnenko, T., Lapham, W.W., Moran, M.J., Rowe, B.L., Squillace, P.J., and Toccalino, P.L., 2006, The quality of our Nation's waters_-Volatile organic compounds in the Nation's ground water and drinking-water supply wells: U.S. Geological Survey Circular 1292, 101 p., http://water.usgs.gov/nawqa/vocs/national assessment/ 